Vol. 8 No. 2 (Juli-Desember) 2021

ISSN: 2355-7982|E-ISSN:2622-5115

http://jurnal.uinsu.ac.id/index.php/komunika

\title{
Instagram: Periklanan Gaya Baru Di Era Kini
}

\author{
Tengku Walisyah \\ Prodi Komunikasi dan Penyiaran Islam, UIN Sumatera Utara \\ shofielittle@gmail.com
}

\begin{abstract}
The widespread use of social media, one of which is Instagram in the current era, is getting higher. Almost everyone has an Instagram account, including those who work as product/service owners. So in order to conduct their product/service offerings, they use this platform very intensely. Photo and video postings in various ways through reels, igtv, or feed, as well as some activities increasingly show that the use increasingly populer. Thus, the effort in sending advertising message nowadays enter a new style era. By using Instagram as one of social media platform advertising gets advanced. Starting from the potentials that exist in the Instagram feature and also activities done by the owner of the product/service in their Instagram account indicates that nowadays advertising looks different.
\end{abstract}

Keywords: Instagram; Advertising; Current Era

\begin{abstract}
Abstrak: Maraknya penggunaan social media salah satunya Instagram pada era kini semakin tinggi. Hampir setiap orang memiliki akun Instagram tak terkecuali mereka yang berprofesi sebagai pemilik produk/jasa. Maka untuk mengupayakan pesan penawaran produk/jasanya mereka memanfaatkan platform yang satu ini dengan sangat intens. Postingan foto maupun video dalam bentuk yang beragam melalui reels, igtv, atau feed serta beberapa aktifitas semakin menunjukkan bahwa pemanfaatannya dalam beriklan semakin populer. Alhasil, upaya penyampaian pesan periklanan kini memasuki gaya baru. Dengan menggunakan Instagram salah satu platform social media periklanan mengalami perkembangan. Mulai dari potensi yang ada dalam fitur Instagram sendiri ditambah dengan aktifitas yang dilakukan oleh pemilik produk/jasa di akun instagramnya mengindikasikan bahwa periklanan kini tampil berbeda.

Kata kunci: Instagram; Periklanan; Era Kii,
\end{abstract}

\section{Pendahuluan}

Dewasa ini seiring perkembangan zaman ditambah dengan kehadiran teknologi yang semakin terbarukan upaya penyampaian pesan khususnya periklanan turut pula mengalami perubahan. Ditandai dengan hadirnya internet plus perangkat yang ada seperti gadget menjadikan periklanan semakin berdinamika dengan kata lain mengalami modifikasi sedemikian rupa. Sejalan dengan pemaparan Monlee Lee dan Carla Johnson bahwa internet telah banyak membawa perubahan besar bagi dunia periklanan (Lee, 2011).

Implikasi lebih lanjut adalah dalam hal media ataupun salurannya. Untuk sampai kepada audience pesan penawaran produk atau pun jasa menggunakan media atau pun saluran yang semakin terbarukan. Mengikuti arus perkembangan zaman kondisi ini menyesuaikan dengan tuntutan zaman yang serba instan dan digital. Ilhamsyah dalam buku Pengantar Strategi Kreatif: Advertising Era Digital menyebutkan bahwa kondisi ini disebutnya sebagai evolusi dalam komunikasi periklanan (Ilhamsyah, 2021).

Kategori media periklanan yang tergolong dalam ranah terbarukan tadi adalah social media. Kehadiran internet plus perangkat yang mumpuni seperti gadget: handphone, tablet, smart watch, smart tv dan sejenisnya menjadi wadah bagi social media berkembang. Tadinya social media hanya sebatas menjalin hubungan komunikasi di antara sesama anggotanya kini berinovasi menjadi sarana menyampaikan pesan penawaran produk atau pun jasa. Social media seperti Facebook, Instagram, Whatssapp, Twitter, Line, dan 
sebagainya merupakan sederet platform yang dilirik para produsen si pemilik produk atau jasa untuk meneruskan pesan penawarannya kepada audience. Para produsen melirik potensi besar yang ada pada platform ini untuk menggaungkan suksesnya pesan penawaran suatu produk/jasa.

Di antara platform tadi salah satu yang paling berkembang pesat sampai hari ini adalah Instagram (Ortiz, 2019). Gaung platform yang satu ini tak diragukan lagi, apalagi saat ini Instagram menambah sarana baru dalam tampilan platform-nya yaitu dengan adanya reels dan toko sehingga ini menambah nilai daya tariknya. Bahkan popularitasnya merambah segala penjuru dunia tidak hanya dalam lingkup nasional tapi juga internasional. Ini mengindikasikan bahwa Instagram berada di masa kejayaannya. Beberapa istilah lahir dari sini dimana ada kata follower, follback (follow back), instastory, selebgram, endorse, review atau me-review dan istilah lain yang jelas semakin menambah besar namanya. Dengan kepopulerannya, pihak produsen melirik potensi besar yang dimiliki Instagram salah satunya dengan memviralkan produk/jasa yang mereka miliki. Dengan harapan bahwa besarnya nama Instagram maka produk/jasa mereka bisa turut besar pula. Belum lagi daya praktis dan instan yang dimilikinya semakin memudahkan pengiklan atau produsen pemilik produk/jasa untuk menawarkan atau mempromosikan pesan iklannya.

Di sisi lain, dalam ranah penelitian selama kurun waktu beberapa tahun sebelumnya telah banyak penelitian yang membahas permasalahan ini. Diantaranya, Heejun Lee dan Chang-Hoan Cho menjelaskan bahwa saat ini dengan kemajuan teknologi periklanan memasuki era digital sehingga hal ini menjadi tantangan bagi pihak yang terlibat dan prospek periklanan ke depan (Lee, Heejun dan Chu, 2019). Berikutnya Susanna Lee dan Eunice Kim meneliti pengaruh influencer atau selebgram ditinjau dari aspek kredibilitas baik secara personal maupun nama besar sang bintang mempengaruhi pesan promosi penawaran suatu produk/jasa yang ditawarkan melalui Instagram (Lee, Susanna dan Kim, 2020). Sementara, Sony Kusumasondjaya dan Fandy Tjiptono membahas tentang periklanan Instagram yang berfokus kepada periklanan makanan melalui endorse oleh orang terkenal atau selebriti. Hasil penelitian menunjukkan bahwa ternyata responden lebih senang dengan penawaran oleh seorang selebriti/selebgram dibanding oleh pakar atau ahli makanan (Kusumasondjaja, S. and Tjiptono, 2019). Penelitian terakhir yaitu dari Daniel Belanche, Isabel Cenjor, dan Alfredo Perez-Rueda menyimpulkan bahwa diantara dua platform yang paling penting digunakan adalah Instagram dan Facebook, namun Instagram memiliki pamor yang lebih unggul dibanding dengan platform satunya lagi. Responden penelitian tersebut adalah kelompok milenial dan non milenial dimana periklanan melalui instagram banyak diminati oleh kaum milenial dan sebaliknya kelompok satu lagi lebih menerima platform Facebook (Belanche, D., Cenjor, I. and Pérez-Rueda, 2019).

\section{Metode Penelitian}

Penelitian ini menggunakan desain penelitian kualitatif sebagaimana dipaparkan Burhan Bungin bahwa terdapat dua tujuan dalam analisis data kualitatif yaitu (1) menganalisis proses berlangsungnya suatu fenomena sosial dan memperoleh gambaran yang tuntas terhadap proses tersebut, dan (2) menganalisis makna yang ada dibalik 
informasi, data, dan proses suatu fenomena sosial itu (Bungin, 2011). Sejalan dengan itu penelitian ini menguraikan tentang fenomena sosial dimana penggunaan media sosial khususnya Instagram sedang marak terjadi mulai dari kurun waktu beberapa tahun terakhir sampai saat ini. Pengumpulan data penelitian ini dilakukan dengan jalan Participant Observation. Lebih jauh Syukur Kholil menjelaskan bahwa pengumpulan data dalam penelitian kualitatif lazim menggunakan metode ini (Kholil, 2016) dimana peneliti bertindak langsung mengamati mulai tahun 2020 sampai 2021 beberapa akun Instagram yang digunakan sebagai sarana periklanan/penawaran dalam memasarkan atau mempromosikan suatu produk/jasa. Akun-akun Instagram yang dijadikan fokus penelitian diambil dari penarikan sampel secara purposif dikenal dengan istilah purposive sampling dimana akun tersebut merupakan representasi dari beberapa akun Instagram yang memanfaatkan periklanan gaya baru salah satunya yaitu dengan jalan me-review produk/jasa yang dipromosikan di akun tersebut.

\section{Hasil Penelitian dan Pembahasan \\ Konvensional Menuju Digital}

Pada masa sebelumnya upaya periklanan membutuhkan beberapa tahapan atau proses dan hitungan biaya dengan nominal yang tidak sedikit. Dalam menyampaikan pesan penawaran produk/jasa tersebut si pemilik produk/jasa biasanya akan menyewa pihak Advertising Agency untuk mendukung upaya ini. Advertising Agency sendiri terdiri dari beberapa tim yang merencanakan, mempersiapkan, memproduksi, dan mendistribusikan iklan (Moriarty, 2011) dan (Morissan, 2010).Untuk memenuhi upaya periklanan yang dilakukan oleh Advertising Agency ini melewati tahapan panjang dan melibatkan beberapa tim. Tim tersebut merumuskan ide kreatif menjadi visualisasi atau secara audio saja atau kombinasi keduanya tergantung pada media iklan yang nantinya dituju. Apakah menggunakan radio, televisi atau media lain menjadi alternatifnya (Madjadikara, 2005).

Setelah iklan selesai diproduksi langkah berikutnya adalah pendistribusian iklan menuju media yang digunakan. Pemilihan media dan penempatannya juga membutuhkan biaya. Secara nominal biaya disesuaikan dengan jenis media yang dipakai dan space penempatannya. Dari sini semakin terlihat bahwa biaya dalam upaya periklanan memakan jumlah besar secara finansial (Vivian, 2008). Oleh karena itu di masa kontemporer saat ini bahkan kini memasuki masa digital dimana-mana serba cepat, praktis, atau instan. Ditandai dengan hadirnya internet menyebabkan perubahan dalam menyampaikan pesan penawaran atau promosi produk/jasa tidak bisa dihindari. Perubahan ini sebagaimana sebelumnya dijelaskan bahwa Ihamsyah menyebutkan evolusi komunikasi periklanan terjadi. Periklanan mengalami modifikasi sedemikian rupa.

Internet telah menghasilkan daya praktis. Kini upaya periklanan atau pemasaran produk/jasa tidak lagi harus melalui tahapan panjang tadi. Mempromosikan bisnis mulai dari mencetak brosur, memasang poster, menyebar kartu nama, sampai dengan memasang iklan di beberapa media seperti surat kabar, radio dan lainnya merupakan upaya periklanan pada masa sebelumnya atau disebut dengan istilah konvensional. Maka kini dengan hanya bermodalkan sesuatu dalam genggaman tangan atau handphone sederet upaya periklanan 
itu sudah bisa dipraktekkan (Helianthusonfri, 2019). Melalui social media periklanan semakin mudah, praktis dan instan. Instagram menjadi salah satu sarana yang mendukung periklanan di era kini yaitu era dimana-mana serba digital.

Selaras dengan itu kini muncul istilah baru yaitu social media marketing. Dalam bahasa sederhana Jefferly Helianthusonfri mendefenisikannya sebagai upaya memasarkan produk/jasa melalui social media dengan cara membuat dan membagikan content (Helianthusonfri, 2019). Sebagaimana fitur utama yang dimiliki instagram yaitu berbagi foto dan video kepada orang-orang menjadi modal dasar untuk para pemilik produk/jasa memanfaatkannya sebagai sarana beriklan. Oleh karena itu sesuai dengan tuntutan zaman yang terus berkembang maka kini pihak yang terkait di dunia periklanan mulai menyesuaikan diri. Ditandai dengan munculnya agensi iklan digital atau digital advertising agency. Adakalanya agensi ini berdiri sendiri khusus menyediakan layanan untuk mendesain atau memproduksi iklan secara digital ataukah berupa divisi khusus di advertising agency besar (Ilhamsyah, 2021). Keahlian mereka dibutuhkan dalam mendesain iklan berbentuk foto atau video dan semacamnya yang dimuat di media-media internet misalkan seperti website, social media (facebook, Instagram, twitter, whatsapp, dan sebagainya), atau media yang sejenis lainnya.

\section{Periklanan Gaya Baru di Era Kini}

Seiring perkembangan zaman saat ini penggunaan social media salah satunya Instagram semakin marak. Hampir semua orang memiliki akun social media ini. Para penggunanya dalam sehari saja sering mengakses platform ini, sehingga keterlibatan para pengguna Instagram sebagai audience dianggap sebagai bahan pertimbangan besar bagi para produsen pemilik produk/jasa menampilkan pesan iklannya di masing-masing akun. Keterlibatan audience Instagram dianggap lebih mewakili potensi keberhasilan periklanan gaya baru ini. Tak salah penjualan online melalui Instagram semakin diminati ditandai dengan maraknya penggunaan iklan gaya baru ini melalui Instagram.

\section{Pemanfaatan Instagram dalam Periklanan}

Dengan wajah baru yaitu menggunakan Instagram sebagai salah satu platform social media periklanan menghasilkan suatu dinamika perkembangan. Ditandai dengan periklanan kini memasuki era digital sehingga lewat sesuatu yang baru ini banyak pihak memanfaatkannya dalam beriklan, sebagaimana tampak pada akun-akun Instagram mereka. Melalui platform ini pemilik produk atau jasa menyebarluaskan pesan promosi dalam beriklan dengan beragam kategori. Mulai dari produk fashion, tas, sepatu/sandal, kuliner (makanan/minuman), perabotan (furniture), perlengkapan rumah, tempat wisata, hotel dan semacamnya sampai kepada jasa seperti desain interior atau bahkan jasa kontraktor bangunan. Selain itu, masih banyak ragam kategori lainnya.

Apakah ditawarkan langsung melalui owner yaitu pemilik produk/jasa ataukah orang lain sebagai asisten turut pula memberikan warna dinamika perkembangan periklanan melaui platform satu ini. Akun-akun yang menggunakan Instagram dalam menawarkan pesan produk/jasanya adalah dari kategori fashion, tas, sepatu dan sendal diantaranya yaitu@twomedantry, @awiekfashionbranded, @hawahijabfashion, 
@ shellasaukiashop, @hijabshop11, @ lekhari, @ houseofvalisha, @annayahijab.official, @ sukriyafashion, @odettemoslem_kids, @ vincci_bna_faulend_store, @vinagabagmedan dan@radwah.

Di bidang kuliner banyak tempat makan maupun minuman yang tak mau ketinggalan ikut memanfaatkan Instagram sebagai sarana untuk mempromosikan tempat usaha mereka. Sebagaimana akun@satemaranggihajiyetti, @sawahlukis, @aljazeerah, @ rotibaba, @ shawarmasultan, @kangbubur, dan @kejukesu, @almasqa.resto populer tidak hanya di satu titik tempat saja melainkan juga merambah pada tempat lain. Begitupun brand besar seperti McD, KFC, Pizza Hut, Ace Hardware, Informa dan semacamnya juga turut merasakan besarnya gaung social media satu ini. Hampir setiap hari akun-akun tersebut memposting informasi terkini atau hanya sebatas mengingatkan produk/jasa mereka masih tetap eksis.

Hal senada dilakukan oleh @makanhalalmedan dimana akun ini adalah akun yang khusus merekomendasikan tempat-tempat kuliner yang halal, enak dan bisa dijadikan referensi untuk dicoba. Setiap harinya atau dalam waktu berkala akun ini memposting tempat kuliner pilihan lengkap dengan video tampilan orang-orang mereka yang mencoba merasakan nikmatnya makanan atau minuman disitu. Tadinya akun ini hanya me-review kuliner di Kota Medan dan sekitarnya kini setelah follower-nya bertambah banyak dan adanya permintaan maka akun ini meluaskan tempat sasaran mereka sampai ke Aceh. Ini menegaskan bahwa pesan penawaran melalui Instagram memang tergolong menggiurkan.

Sementara di bidang perabotan (furniture) atau perlengkapan rumah, dan semacamnya diwakili oleh akun @interiorcantik, @hommy_living, @shafafurniture, @aminshofa,dan@leatique_deco. Begitupula pada kategori tempat wisata dan hotel seperti Siosar, Taman Air Percut, The Lehu Garden, Madu Efi, The Anmon Resort Bintan, Cinnamon Boutique Syariah (Hotel Syariah Bintang 4 di Bandung) dan sebagainya turut pula memanfaatkan Instagram sebagai sarana beriklan pada era kini.Di kalangan artis, selebriti, atau tokoh-tokoh yang memiliki nama besar juga ikut merasakan besarnya pengaruh yang dihasilkan oleh Instagram. Perhatikan bagaimana Oki Setiana Dewi, Ashanty, Atta Halilintar, Ria Ricis, Shareena, Taqy Malik, Arie Kuntung, Natalie Sarah, Deddy Corbuzier dan lainnya sering membagi postingan cerita kehidupan sehari-hari mereka. Baik melalui kiriman cerita di instastory mereka atau postingan Instagramnya. Ini mengindikasikan bahwa mereka sedang mengupayakan eksistensi keberadaan di balik nama besar mereka. Sekaligus bertujuan untuk mempertahankan brand mereka agar tak lekang dimakan waktu. Pada tahap berikutnya tentu upaya ini akan membangun kesadaran brand di benak audience. Sehingga kondisi ini nantinya menciptakan brand yang begitu kuat.

Dari kalangan yang sudah terkenal dan memiliki nama besar sampai kepada orangorang biasa memanfaatkan Instagram. Bahkan sebagian dari mereka menjadi populer, viral, dan terkenal karena Instagram. Sehingga muncul istilah yang disebut dengan selebgram atau selebriti di Instagram. Lewat media ini nama mereka semakin besar ditandai dengan jumlah follower mereka semakin hari semakin bertambah. Potensi yang mereka miliki juga beragam ada yang sukses menjadi model endorse di Instagram seperti Nabila, Cut Melisa, dan Ayu Hairotin Nisa, Larissa Chou khusus mengiklankan langsung beragam produk/jasa. 
Ada yang memiliki skill sebagai content creator dengan tampilan cerita unik, lucu, atraktif, dibantu dengan visualisasi teknologi komputer canggih hasilnya sangat menghibur para follower-nya sebagaimana diupayakan oleh @alfysaga beserta istrinya @fatmasarizar juga @ harbatah dengan pasangannya @ sasa_alaydrus.

Belum lagi di kalangan ibu-ibu yang memiliki keahlian memasak turut menjadikan Instagram sebagai sarana yang tepat untuk mensukseskan pesan promosi brand di balik nama mereka. Sebut saja @ tintinrayner, @dapur_lindawaty, @ restuutamidewi, @dokterkoki,@sukmawati_rs, @umi_halim, @ deviirwantari, @ isnasutanto, @ chechekitchen dan @aras_galeri senantiasa memposting beberapa resep-resep masakan berikut cara mengolahnya lengkap dengan rincian langkah-langkahnya. Belum lagi postingan sederhana tapi banyak mengandung pesan positif kebaikan dari seorang ibu Fitriani Handayani. Dia mengajarkan bagaimana mengatur keuangan dengan hemat di tengah budget yang pas-pasan setiap bulannya sampai kepada memperindah rumah dengan low budget dan pesan kebaikan lainnya membuat para audience yang berasal dari kalangan ibu merasa terbantu dengan solusi yang diberikannya. Hasilnya, follower-nya bertambah dan dia pun sering diminta untuk meng-endorse beberapa produk/jasa.

Pemanfaatan Instagram juga merambah skala global dengan kemampuan yang dimiliki social media satu ini juga turut menambah besar pemanfaatannya. Jangkauan luasnya mampu menembus ruang, waktu dan audience dalam jumlah besar ke segala penjuru dunia. Alhasil, ini membuat bintang besar di kancah internasional turut pula memanfaatkanya. Salah satu contoh adalah Mehmet Chef, Dr. Mehmet Oz atau Dr. Oz, Maheer Zain, Taylor Swift, Oprah Winfrey, Meghan Markle, Celine Dion, Shania Twain sampai kepada keluarga kerajaan Inggris dalam akun @dukeandduchessofcambridge juga memanfaatkan Instagram untuk menyebarluaskan pesan informasi kepada audience mereka.

Brand besar seperti Bolde melalui akunnya @bolde_store dan Pero di akun @ pero.indonesia juga ikut memanfaatkan Instagram untuk mempromosikan produk-produk mereka. Di bidang fashion internasional misalnya saja pemilik brand besar berasal dari Turki Modanisa yang cukup berpengaruh dan telah memiliki situs penjualan online $e$ commerce dimana produknya telah tersebar tidak hanya di Turki, Australia, Uni Eropa, dan Amerika Serikat juga tak mau ketinggalan memanfaatkan Instagram sebagai sarana untuk menawarkan dan mempromosikan produknya tersebut (Saparini, 2018). Armine juga brand yang sudah mengglobal berasal dari Turki turut pula memanfaatkan Instagram. Sama halnya dengan brand DKNY, Nike, Zara dalam berkala memposting produknya di Instagram.

Pada kategori lain yaitu dalam penyampaian pesan dakwah ternyata melalui Instagram beberapa tokoh seperti Ustadz Adi Hidayat, Ustadz Hanan Attaki juga sang istri Ustadzah Haneenakira, Ustadz Abdul Somad, dan lainnya juga tak kalah ikut meramaikan pemanfaatan Instagram ini. Tokoh-tokoh tadi menggunakan Instagram dalam bentuk nasehat-nasehat kebaikan untuk mengajak dan mengingatkan para audience dalam hal kebaikan di dunia maupun di akhirat. 
Sederet nama-nama tadi jelas menunjukkan bahwa upaya dalam penyampaian pesan periklanan suatu produk/jasa melalui Instagram saat ini mengalami perkembangan yang sangat pesat. Akibatnya pemanfaatan Instagram dalam periklanan menghasilkan dinamika perkembangan baru. Selain nama-nama ataupun akun Instagram yang telah disebutkan tersebut masih banyak lagi akun atau pun produsen pemilik produk/jasa lain yang memanfaatkan Instagram sebagai sarana tidak hanya untuk bersosialisasi di dunia online tapi juga dengan tujuan untuk mempromosikan sekaligus meluaskan bisnis mereka. Hal inilah yang mendasari bahwa Instagram kini sangat diminati kalangan pebisnis untuk mensukseskan pesan penawaran produk/jasa mereka.

\section{Eksistensi Periklanan Gaya Baru di Instagram}

Begitu besarnya pemanfaatan Instagram dalam upaya penyampaian pesan kepada audience dengan segala potensi yang ada padanya, maka kehadirannya kini menghasilkan periklanan dalam gaya yang berbeda. Sandra Moriarty pun menegaskan bahwa adanya bentuk komunikasi baru yang dilahirkan periklanan melalui media internet ini yaitu lebih dekat, interaktif, dan personal (Moriarty, 2011). Bentuk komunikasi ini menghasilkan periklanan dengan tampilan yang berbeda dari biasanya. Periklanan kini mengalami evolusi perkembangan.

Eksistensi periklanan gaya baru ini dengan karakter yang disebut lebih dekat terjalin antara produsen pemilik produk/jasa sebagai komunikator yang mengirimkan pesan iklannya kepada follower-nya sebagai audience/komunikan penerima pesan iklannya. Dengan fitur khusus yang dimilikinya Instagram memiliki kemampuan dalam hal ini yang tidak dimiliki oleh platform lainnya. Instagram mengupayakan jalinan kedekatan relasi antara kedua belah pihak. Diantaranya membangun relasi internal yaitu menghidupkan ikatan batin secara emosional/feeling antara produsen dengan konsumen atau calon konsumennya. Ini menyebabkan bagaimana periklanan melalui Instagram paling digemari (Ortiz, 2019).

Frekuensi intensitas pesan komunikasi yang senantiasa dilancarkan oleh pihak produsen kepada audience-nya semakin menegaskan bahwa kedekatan jelas terjalin. Melalui postingan atau suatu informasi atau pesan komunikasi yang dikirimkan/di-share secara berkala dan intens di akun Instagram mereka memperkuat kondisi demikian. Bagaimana keterhubungan atau kedekatan yang jelas dibangun dan diupayakan semakin terlihat. Dalam sehari si pemilik produk atau jasa memposting atau membagi kiriman pesan produk/jasanya dengan beberapa kali kiriman. Kiriman tersebut berupa postingan di feed ataupun di instastory dalam bentuk foto maupun video.

Pesan-pesan tersebut dikirimkan secara berkali-kali walaupun kiriman foto/videonya tidak memuat content yang sama sehingga kiriman/postingannya bertambah banyak. Dengan frekuensi atau intensitas pengiriman yang sering dan berkali-kali ini menunjukkan adanya prinsip periklanan. Dimana prinsip ini disebut sebagai repetisi (Liliweri, 2011) atau pun terpaan dalam periklanan. Ini berfungsi untuk memanggil kembali ingatan audience tentang produk/jasa yang ditawarkan atau untuk menyegarkan ingatan 
audience. Alhasil, identifikasi terhadap brand suatu produk/jasa akan terus bertahan atau tetap bisa eksis.

Apalagi dewasa ini produk pesaing atau kompetitor semakin bermunculan. Sehingga yang menjadi tantangannya adalah melahirkan content periklanan di Instagram yang lebih atraktif. Dengan memuat content beragam tidak melulu seputar pesan produk/jasa saja melainkan memunculkan informasi lain yang bernilai positif. Mulai dari content dakwah Islam mengajak pada kebaikan Islam, content edukasi yang ringan pun bisa jadi alternatif bahkan sampai kepada content kehidupan pribadi si owner sebagai pihak produsen pemilik produk/jasa menambah nilai dalam upaya membangun relasi dekat kepada follower sebagai audience.

Perhatikan bagaimana Taqy Malik sebagai pengusaha saffron sukses yang memanfaatkan Instagram untuk mempromosikan atau menawarkan produknya. Akun instagramnya sering memposting instastory seputar kehidupan pribadinya, bagaimana kesehariannya beserta pasangannya Sherel Thalib, mereka aktif ber-social media melalui Instagram. Di samping postingan-postingannya tentang produk yang dia miliki, Taqy Malik menyelingi postingan tersebut tidak hanya dengan cerita kehidupan pribadi atau kesehariannya, bahkan postingan ceritanya merambah kepada hal-hal lucu yang sering dia lakukan atau ucapkan. Ini menambah nilai dekat yang dibangun kepada para follower-nya. Tak jarang juga dia memberikan hadiah kepada mereka yang disebut dengan istilah give away. Sehingga hal ini jelas semakin menandakan bahwa kedekatan secara emosi sedang diupayakan antara owner dengan follower-nya. Sama halnya dengan Tanna Dewi Shanti kerap memposting instastory kehidupan pribadinya. Bagaimana kesehariannya, apa saja yang dia lakukan, makan, minum, dan semua kegiatannya menjadi alternatif tontonan yang cukup menghibur para follower-nya, selain kiriman atau postingan jualan. Kesemua aktifitas itu menunjukkan bahwa para pemilik produk tadi sedang membangun jalinan kedekatan antara dirinya, produknya, dengan follower-nya.

Selanjutnya, nilai interaktif yang dimiliki Instagram memuat adanya kemampuan untuk saling berkomunikasi seketika itu juga antara produsen sebagai komunikator dengan audience sebagai follower-nya. Pesan yang disalurkan bisa direspon langsung. Dari setiap postingan atau instastory yang dikirimkan berpeluang untuk mendapatkan feedback/respon kembali. Ini sekaligus menunjukkan bahwa Instagram menghasilkan model periklanan yang interaktif pula. Keuntungan tidak hanya dirasakan oleh pihak produsen secara komersialisasi namun juga dengan daya interaktif ini konsumen selaku audience bisa merasakan kepuasan maksimal dalam berbelanja online melalui pilihan produk/jasa yang ditawarkan, sebab konsumen berkesempatan besar untuk bertanya banyak hal dan langsung mendapatkan jawaban/informasinya tentang produk/jasa tersebut.

Daya interaktif ini didukung oleh fitur live atau siaran langsung dimana pemilik produk/jasa berkesempatan menayangkan siarang langsung untuk menawarkan produk/jasanya. Ditambah lagi fitur igtv yang menayangkan video-video yang disebut sebagai siaran tivi berdurasi beberapa waktu sekaligus di dalam tampilan Instagram sendiri yang memuat adanya foto dan video dalam setiap postingan atau kirimannya yang juga bisa direspon langsung oleh audience-nya, semakin menambah nilai interaktif yang ada. 
Sementara untuk nilai personal dalam beriklan melalui Instagram ditandai dengan penggunaan foto dan video dalam akun Instagram dari produsen pemilik produk/jasa tersebut ditujukan hanya kepada sekelompok orang tertentu saja. Dengan kata lain pemasaran atau penawaran suatu produk/jasa melalui Instagram hanya khusus ditujukan kepada orang-orang tertentu dari kategori follower yang memiliki minat yang sama. Biasanya para follower ini hanya akan mengikuti suatu akun Instagram yang disuka/disenangi. Sehingga fokus penyampaian pesan periklanan semakin personal. Hal ini menyebabkan segmentasi pasar periklanan menjadi mudah diupayakan oleh para produsen. Seperti Tanna Dewi Shanti yang hanya mengupayakan fokus penjualan produknya kepada para kaum ibu atau sering disebutnya dengan istilah "emak-emak". Follower yang menjadi audience-nya banyak berasal dari kalangan ibu-ibu golongan menengah ke atas dengan kebutuhan baju-baju gamis dan perlengkapannya: hijab, sepatu, sandal, tas dan sejenisnya. Barang-barang ini merupakan produk yang selalu di-review saat melakukan live dan merupakan content postingan atau kiriman instastory-nya.

Taqy Malik khusus menyasar target market dari kalangan anak muda dengan produknya berupa saffron khusus yang didatangkan dari Kashmir. Sehingga karakter produk baik dari kemasan maupun variannya disesuaikannya dengan selera anak muda. Selain itu, content instagramnya pun berisi hal-hal yang up too date/kekinian. Dua hal ini menjadi bahan content di setiap postingan atau kiriman yang disukai oleh para folower-nya yang juga dari kalangan anak muda. Begitupun dengan brand Radwah yang mengkategorikan produknya untuk remaja atau anak muda, sehingga content instagramnya senantiasa mengusung tema yang berkaitan dengan itu.

Sekali lagi semua kondisi tadi semakin menegaskan bahwa saat ini periklanan telah memasuki gaya baru dimana sederet pihak yang telah disebutkan semula bertindak sebagai pemilik suatu produk atau jasa menggunakan periklanan gaya baru dalam menawarkan atau mempromosikan bisnis mereka. Mulai dari menggunakan atau memanfaatkan akun instagramnya untuk membagikan foto-foto atau video seputar pesan penawaran produk/jasa mereka sampai berbagi kehidupan pribadi menjadi cara tersendiri sebagai indikasi munculnya gaya baru dalam periklanan melalui platform ini.

Selain beberapa bentuk komunikasi baru yang hadir dalam periklanan Instagram sebagaimana penelusuran sebelumnya masih banyak kriteria lain yang mendukung munculnya gaya baru dalam periklanan. Diantaranya adalah adanya fenomena me-review atau secara sederhana disebut sebagai cara menggambarkan dengan sangat rinci atau detail suatu produk/jasa yang ditawarkan di Instagram. Sehingga walaupun audience tidak langsung bisa menyentuh/memegangnya secara fisik namun dengan rincian gambaran atau penjelasan yang diberikan melalui postingan video baik melalui igtv, reels, maupun live maka audience bisa puas mendapatkan keterangan/informasinya.

Melalui kegiatan me-review dimana ini merupakan bentuk komunikasi yang dilancarkan oleh pemilik akun Instagram atau owner produk/jasa yang memposting kiriman foto dan video atau melakukan live di akunnya sekali lagi menunjukkan bahwa ini termasuk periklanan dengan gaya baru. Ditambah lagi dengan potensi interaktifnya saat aktifitas me- 
review itu dilakukan baik secara live ataupun tidak audience yang melihat bisa langsung memberikan respon.

Hal inilah yang senantiasa diupayakan oleh beberapa pihak pemilik produk/jasa dalam akun instagramnya yaitu me-review produk/jasanya dalam waktu berkala. Seringnya, aktifitas ini dilakukan pada saat live berlangsung di akun Instagram untuk menginformasikan produk/jasa yang baru diproduksi atau di-release kepada audience. Barang kali aktifitas me-review suatu produk/jasa ini sudah sering diupayakan lewat media lain bukan hanya Instagram bahkan penggunaannya juga jauh sebelumnya telah pula dilakukan. Namun perlu digarisbawahi penggunaan aktifitas ini menjadi berbeda dan sesuatu yang baru adalah karena penggunaannya di Instagram sebagai sarana social media, dimana potensi untuk interaktif jelas bisa ditempuh. Artinya hanya dengan menggunakan social media yaitu Instagram audience sebagai follower bisa langsung memberikan respon saat postingan content produk/jasa ditawarkan. Mereka bisa langsung memberikan tanggapan apakah suka terhadap produk/jasanya atau tidak. Kalau suka dan tertarik ingin membeli bisa memesannya berdasarkan petunjuk yang diberikan pada saat aktifitas ini diposting. Saling berkomunikasi antara pemilik akun yang menawarkan produk/jasanya kepada audience inilah yang menyebabkan periklanan jenis ini tergolong berbeda, tampil dengan sesuatu yang baru. Lebih lanjut potensi ini disebut dengan istilah tadi yaitu interaktif.

Di sisi lain, keunggulan Instagram dibanding social media lainnya adalah dalam hal fitur yang ada, Instagram menyediakan ruang yang besar untuk berbagi foto maupun video dalam bentuk beragam seperti instastory, reels, maupun live. Tampaknya nilai atraktif inilah yang menyebabkan pamor dari media yang satu ini tinggi. Sebagaimana dijelaskan oleh Claire bahwa suksesnya periklanan melalui Instagram sejatinya diawali dari suatu formula yaitu formula berbagi atau share (Ortiz, 2019). Share apa saja dengan content yang beragam dan tetap fokus terhadap produk/jasa yang ditawarkan.

Diantara pihak produsen yang senantiasa melakukan aktifitas me-review di akun instagramnya sebut saja Tanna Dewi Shanti. Seorang pengusaha sukses di bidang fashion, memiliki butik dengan brand Hijabshop11 menjual perlengkapan wanita dan di sebelahnya juga ada sebuah Café yaitu Coffeeshop11 miliknya untuk tempat makan dan minum. Tanna sendiri lebih memilih melakukan live setiap hari pada jam tertentu untuk me-review produknya sekaligus menginformasikan para follower-nya mengenai produk yang baru muncul tersebut. Saat melakukan aktifitas itu dia memakai produknya sambil di-review apakah itu baju gamis, hijab, tas, parfum, maupun sepatu atau pun sendal. Interaktif pun berlangsung pada saat itu juga sehingga follower-nya banyak yang memberikan tanggapan. Hanya dengan hitungan beberapa detik atau menit produk yang ditawarkannya habis terjual/sold out dengan cara pesan terlebih dahulu kemudian transfer sejumlah duit ke rekeningnya. Dan ini sering terjadi produknya sold out seketika saat live me-review dilakukannya.

Senada dengan apa yang dilakukan oleh Tanna Dewi Shanti, produk dengan brand Radwah ikut pula mempraktekkan periklanan gaya baru ini. Dimana produk ini merupakan produk fashion yang tersegmentasi untuk anak-anak muda, baik wanita maupun pria. 
Dimulai dari gamis, hijab, tas, mukena, perlengkapan laki-laki: baju koko, celana panjang, dan lain-lain adalah content yang ditawarkan dalam postingan live di akun Instagramnya. Melalui siaran langsung atau live setiap Radwah me-review produknya maka hanya hitungan durasi waktu sebentar saja produk pun sold out. Belum lagi produk saffron dengan brand Taqychan Saffron juga ikut memakai cara periklanan gaya baru ini dengan mereview produknya yaitu saffron khas dari Kashmir. Saffronnya terbilang langka berwarna merah terang dan ketika dicampur ke dalam air maka airpun langsung berubah warna menjadi kuning. Cukup tiga helai saja dimasukkan maka perubahan warna tersebut bisa langsung terlihat sebagaimana ditampilkan saat review produk dilakukan. Sehingga hal inilah yang membuat produknya laris manis ditambah kepiawaiannya memanfaatkan Instagram sebagai sarana beriklan dengan jalan interaktif biasanya melalui instastory di akunnya. Apalagi saat si owner Taqy Malik memposting promo harga untuk kategori produknya yang bermacam-macam, maka respon followers-nya luar biasa.

Akun Instagram lainnya juga turut memanfaatkan periklanan gaya baru dengan bentuk live di Instagram ini. Sebut saja @ shellasaukiashop, yang sukses sebagai agen besar penyalur atau penyedia pakaian wanita berhijab juga senantiasa meriview produk yang ditawarkan melalui postingan live instagramnya. Dengan bantuan beberapa asisten dan owner-nya merincikan produk fashion mereka. Begitupun dengan @ vinagabagmedan akun yang senantiasa menawarkan produknya berupa tas melalui siaran langsung di akun instagramnya. Tak ketinggalan akun lain @hijaboutfit_shop, @ clothtowear, @ nayakahijab_hilda, @alzena.kidsmoslem,juga turut mengupayakan periklanan gaya baru dengan cara melakukan live di akunnya untuk menawarkan produk mereka kepada follower-nya.

Selain itu, akun seperti @shafafurniture yang menawarkan produk perabotan/furniture di akun instagramnya dengan gaya baru me-review produknya secara detail lengkap dengan tampilan videonya. Selaras dengan itu @leatique_deco turut menggunakan periklanan gaya baru ini yaitu juga me-review hampir seluruh produknya dari perlengkapan rumah atau aksesoris pelengkap untuk memperindah rumah dimana sebagian besar produknya berasal dari barang import. Kedua akun ini kerap memposting iklan gaya baru ke dalam instastory akun Instagram mereka. Periklanan gaya baru di Instagram ditambah dukungan dari fitur igtv yang memuat postingan video turut pula menambah ragamnya periklanan baru ini. Masih pada kategori fashion oleh akun @hawahijabfashion1 sering memposting iklan produknya melalui fitur ini. Akun @ didiksubi menggunakan igtv dan reels dalam postingan instagramnya menawarkan pesan iklan usahanya di bidang kontraktor bangunan dengan nama PT. Bintoro Sinergi Korpora dan PT. Bintoro Bangun Indonesia.

Untuk teknisnya, sebagian akun menggunakan asisten atau pekerjanya untuk menampilkan produk/jasa yang ditawarkan, ada juga owner atau si produsen yang mengisi acara langsung tersebut sampai selesai sekaligus mempromosikan produk/jasanya sendiri. Tanna selaku pemilik brand hijabshop11 senantiasa konsisten me-review sendiri produknya di hampir setiap postingannya. Walaupun beberapa kali dia menggandeng orang lain misalkan teman-temannya atau adiknya namun dia sendiri tetap konsisten me-review 
produknya saat live berlangsung. Adakalanya akun Instagram yang mereka miliki merupakan akun pribadi sekaligus merangkap sebagai akun penawaran produk atau jasa yang mereka punya. Tak sedikit pula sebagian dari mereka memiliki beberapa akun dimana akun pribadi terpisah dengan akun bisnis mereka. Seperti Tanna Dewi Shanti memiliki akun@hijabshop11, @home11tanna, @tannadewishanti, dan @ cofeeshop11. @ taqychansaffron merupakan akun bisnis yang dimiliki oleh owner-nya dengan akun @ taqymaliknewdan @dendychaniago sebagai owner@radwah.

Tampaknya periklanan semacam ini terbilang cukup sukses dan efektif terbukti dengan banyaknya respon positif dari para follower dengan memesan dan membeli produk yang sedang ditawarkan apakah melalui live maupun postingan instastory, igtv, reels, ataupun postingan video saja. Bahkan periklanan gaya baru ini sudah menjadi trend atau populer di kalangan para produsen pemilik produk/jasa. Kini mereka sering mengupayakan pesan penawaran produk/jasa dengan jalan me-reviewnya di akun Instagram mereka.

Melalui penggunaan periklanan gaya baru lewat review produk/jasa di Instagram melahirkan istilah endorse/endorsement. Kalau yang dipraktekkan beberapa akun yang telah disebutkan semula adalah bagian dari upaya periklanan yang dijalankan oleh owner sendiri, maka untuk istilah ini merupakan bentuk kegiatan dalam kategori mempromosikan atau mengiklankan suatu produk/jasa dengan jalan menyuruh orang lain melakukannya. Dengan kata lain adanya anjuran yang diberikan sebagai alternatif rekomendasi suatu produk/jasa yang ingin dibeli/dipakai.

Orang yang dipilih untuk melakukan review produk/jasa tersebut adalah orang yang memiliki follower banyak, namanya cukup populer di jagat maya online Instagram. Sederet nama-nama seperti Nabila, Cut Melisa, Ayu Hairotin Nisa, Alfysaga, Fatmasarizar, Larissa Chou merupakan tokoh besar dan cukup berpengaruh di Instagram. Selanjutnya dari aktifitas endorsement melalui Instagram mereka disebut sebagai selebgram. Istilah untuk menyebutkan selebriti Instagram. Nabila dan Cut Melisa adalah tokoh yang populer dengan postingan endorse mereka. Bahkan kadang-kadang mereka diminta untuk khusus tampil berdua meng-endorse sehingga disebut dengan endorse twin. Mereka mempromosikan produk/jasa orang lain dan membantunya agar produk/jasa tersebut laris manis. Nabila sendiri bahkan dikenal dengan istilah Ratu Endorse dalam sehari saja banyak produk/jasa yang bisa dia tampilkan saat melakukan aktifitas ini di akunnya.

Di sisi lain Alfysaga dengan Fatmasarizar dan@ @ harbatah dengan@sasa_alaydrus pasangan suami istri dari kalangan content creator yang memiliki ide kreatif, unik, dan cukup menghibur saat meng-endorse suatu produk/jasa. Mereka memanfaatkan unsur teknologi plus humor dalam setiap tampilan video yang dikirimkan di akun mereka masingmasing. Begitu pun Larissa Chou yang banyak mendapatkan tawaran untuk mengiklankan produk/jasa orang lain yang disebut endorse ini. Ayu Hairotin Nisa juga termasuk salah satu selebgram yang turut mendapatkan tawaran untuk meng-endorse beberapa produk/jasa di akun instagramnya.

Begitu populernya periklanan melalui Instagram ini sehingga menjadi trend dan menghasilkan profesi baru yaitu sebagai selebgram, ratu/bintang endorse, content creator atau influencer sebagaimana dilakukan oleh sederet nama-nama yang telah disebutkan 
semula. Dari kalangan orang terkenal seperti artis pun juga tak kalah saing ikut meramaikan periklanan gaya baru ini dengan meng-endorse beberapa produk/jasa di akun Instagram mereka seperti Aurel, Ashanty, Shareena, Ria Ricis dan artis lainnya. Dari penyiar Radio dengan nama Sahil Mulachela beserta istrinya Rania Alaydrus banyak mendapatkan tawaran endorse di akun instagramnya. Sementara dari kalangan ibu-ibu rumah tangga yang senang dengan memasak dan menjadi hobinya ikut juga memanfaatkan periklanan gaya baru ini. Dimana diawali dengan seringnya memposting masakan dan membagi resepnya di postingan kiriman foto dan video instagramnya menghasilkan follower yang bertambah banyak. Sehingga ini menyebabkan nama mereka menjadi populer sekaligus masakannya menjadi produk yang dijual karna diminati follower-nya. Lewat akun @ restuutamidewi, @mamitoko dan @dokterkoki terlihat bagaimana mereka merintis kepopuleran mereka sekaligus mereka ikut mempraktekkan bagaimana upaya dalam pengiriman pesan penawaran produk mereka melalui Instagram. Adalagi dari kalangan ibu rumah tangga yang khusus menyebarkan pesan-pesan positif seperti @ayie_stroberi. Dan dalam hal bagaimana mengatur keuangan seadanya dengan bijaksana agar pengeluaran bisa ditekan sebagaimana yang dipraktekkan oleh akun @fi3_an1 dengan jumlah follower banyak maka hampir setiap hari ada saja postingan produk-produk yang di-endorse di akunnya.

Melalui penelusuran beberapa aktifitas yang terjadi di banyak akun Instagram tersebut semakin menegaskan bahwa memang periklanan saat ini sedang memasuki wajah baru dalam perkembangannya. Yaitu dimana periklanan kini berganti dengan gaya baru dengan bentuk yang lebih dekat, interaktif, dan personal sebagaimana dijelaskan oleh Sandra Moriaty. Masing-masing aktifitas pada akun-akun tersebut menandakan bahwa periklanan dengan gaya baru ini lebih efektif dan terbilang sukses. Ditandai dengan beberapa keberhasilan atau kesuksesan dalam mendulang nama besar atau pun popularitas baik brand produk/jasanya maupun brand orangnya sendiri sebagai owner/pemilik produk/jasa. Keterhubungan antara keduanya baik brand produk plus brand nama individu pemilik produk/jasanya menjadi kombinasi yang efektif dalam mempraktekkan periklanan gaya baru melalui platform social media satu ini.

\section{Penutup}

Alhasil dengan maraknya upaya dalam menyampaikan pesan promosi atau penawaran suatu produk/jasa melalui Instagram sebagaimana telah dipaparkan sebelumnya melalui beragam akun mendukung kegiatan ini terlihat bahwa periklanan dengan gaya baru terbilang cukup sukses. Sebagaimana telah dijelaskan sebelumnya bahwa periklanan gaya baru ini menghasilkan penjualan produk/jasa yang stoknya cepat habis terjual atau sold out.

Beberapa faktor turut menjadi alasan mengapa periklanan gaya baru ini terbilang sukses. Pertama, iklan melalui Instagram ini kesannya natural (alami), tidak dipaksakan, mengalir seperti biasa. Tidak terkesan sedang beriklan, tapi terlihat menyatu dengan dirinya sendiri sehingga ketika audience menikmati endorse atau review produk yang dirasakan 
adalah bahwa tokoh itu memang benar-benar membeli produk tersebut bukan hasil dari barang endorse.

Selanjutnya adalah nilai instan dan praktis. Berbekal hanya dengan perangkat seadanya yaitu handphone orang sudah bisa beriklan yaitu dengan cara memposting review produk sendiri atau endorse produk orang lain. Hal ini semakin menandakan bahwa periklanan gaya baru ini simple, cepat, ketika diposting saat itu juga bisa langsung dinikmati oleh audience. Terlebih lagi hemat biaya atau pemangkasan biaya iklan merupakan faktor berikutnya dalam pemilihan periklanan melalui Instagram dibanding dengan model konvensional yang menggunakan perantara pasar, karena audience bisa langsung berkomunikasi dengan pihak produsen (Kertamukti, 2015).

Jadi, berangkat dari kondisi yang beragam tadi semakin menunjukkan bahwa pada era kini periklanan sedang mengalami perkembangan dan dinamikanya sesuai dengan pertumbuhan hadirnya media baru yang menjadi roda berputarnya upaya periklanan ini.

\section{DAFTAR PUSTAKA}

Belanche, D., Cenjor, I. and Pérez-Rueda, A. (2019). Instagram Stories versus Facebook Wall: an advertising effectiveness analysis. Spanish Journal of Marketing - ESIC, 23(1), 69-94. https://doi.org/10.1108/SJME-09-2018-0042

Bungin, B. (2011). Penelitian Kualitatif: Komunikasi, Ekonomi, Kebijakan Publik, dan Ilmu Sosial Lainnya (Kedua Ceta). Prenada Media Group.

Helianthusonfri, J. (2019). Belajar Social Marketing. Gramedia.

Ilhamsyah. (2021). Pengantar Strategi Kreatif: Advertising Era Digital. ANDI.

Kertamukti, R. (2015). Strategi Kreatif dalam Periklanan: Konsep Pesan, Media, Branding, Anggaran. Rajawali Pers.

Kholil, S. (2016). Metodologi Penelitian Komunikasi. Perdana Publishing.

Kusumasondjaja, S. and Tjiptono, F. (2019). Endorsement and visual complexity in food advertising on Instagram. Internet Research, 29(4), 659-687. https://doi.org/10.1108/IntR-11-2017-0459

Lee, Heejun dan Chu, C.-H. (2019). Digital Advertising: Present and Future Prospects. International Journal of Advertising, 39(3), 332-341.

Lee, M. and C. J. (2011). Prinsip-prinsip Pokok Periklanan dalam Perspektif Global. Kencana.

Lee, Susanna dan Kim, E. (2020). Influencer marketing on Instagram: How sponsorship disclosure, influencer credibility, and brand credibility impact the effectiveness of Instagram promotional post. Journal of Global Fashion Marketing, 11(3), 232-249. https://doi.org/10.1080/20932685.2020.1752766

Liliweri, A. (2011). Komunikasi Serba Ada Serba Makna. Kencana.

Madjadikara, A. S. (2005). Bagaimana Biro Iklan Memproduksi Iklan: Bimbingan Praktis Penulisan Naskah Iklan (Copywriting). Gramedia.

Moriarty, S. et. a. (2011). Advertising. Kencana.

Morissan. (2010). Periklanan: Komunikasi Pemasaran Terpadu. Kencana.

Ortiz, C. D. (2019). Social Media Success for Every Brand. Buana Ilmu Populer. 
Instagram: Periklanan Gaya...-Walisyah

Saparini, H. dkk. (2018). Bisnis Halal: Teori dan praktek. Rajawali Pers.

Vivian, J. (2008). Teori Komunikasi Massa. Kencana. 